\title{
Infodemiology and Infoveillance: Scoping Review
}

\author{
Amaryllis Mavragani, BSc, MSc \\ Department of Computing Science and Mathematics, Faculty of Natural Sciences, University of Stirling, Stirling, United Kingdom
}

\section{Corresponding Author:}

Amaryllis Mavragani, BSc, MSc

Department of Computing Science and Mathematics

Faculty of Natural Sciences

University of Stirling

University Campus

Stirling, FK9 4LA

United Kingdom

Phone: 447523782711

Email: amaryllis.mavragani1@stir.ac.uk

\begin{abstract}
Background: Web-based sources are increasingly employed in the analysis, detection, and forecasting of diseases and epidemics, and in predicting human behavior toward several health topics. This use of the internet has come to be known as infodemiology, a concept introduced by Gunther Eysenbach. Infodemiology and infoveillance studies use web-based data and have become an integral part of health informatics research over the past decade.

Objective: The aim of this paper is to provide a scoping review of the state-of-the-art in infodemiology along with the background and history of the concept, to identify sources and health categories and topics, to elaborate on the validity of the employed methods, and to discuss the gaps identified in current research.

Methods: The PRISMA (Preferred Reporting Items for Systematic Reviews and Meta-Analyses) guidelines were followed to extract the publications that fall under the umbrella of infodemiology and infoveillance from the JMIR, PubMed, and Scopus databases. A total of 338 documents were extracted for assessment.

Results: Of the 338 studies, the vast majority ( $n=282,83.4 \%$ ) were published with JMIR Publications. The Journal of Medical Internet Research features almost half of the publications ( $n=168,49.7 \%)$, and JMIR Public Health and Surveillance has more than one-fifth of the examined studies $(n=74,21.9 \%)$. The interest in the subject has been increasing every year, with 2018 featuring more than one-fourth of the total publications $(n=89,26.3 \%)$, and the publications in 2017 and 2018 combined accounted for more than half $(n=171,50.6 \%)$ of the total number of publications in the last decade. The most popular source was Twitter with $45.0 \%(n=152)$, followed by Google with $24.6 \%(n=83)$, websites and platforms with $13.9 \%$ ( $n=47)$, blogs and forums with $10.1 \%(n=34)$, Facebook with $8.9 \%(n=30)$, and other search engines with $5.6 \%(n=19)$. As for the subjects examined, conditions and diseases with $17.2 \%(n=58)$ and epidemics and outbreaks with $15.7 \%(n=53)$ were the most popular categories identified in this review, followed by health care $(n=39,11.5 \%)$, drugs $(n=40,10.4 \%)$, and smoking and alcohol $(n=29,8.6 \%)$.

Conclusions: The field of infodemiology is becoming increasingly popular, employing innovative methods and approaches for health assessment. The use of web-based sources, which provide us with information that would not be accessible otherwise and tackles the issues arising from the time-consuming traditional methods, shows that infodemiology plays an important role in health informatics research.
\end{abstract}

(J Med Internet Res 2020;22(4):e16206) doi: $\underline{10.2196 / 16206}$

\section{KEYWORDS}

big data; infodemiology; infoveillance; internet; review; web-based data

\section{Introduction}

Infodemiology (ie, information epidemiology) is a field in health informatics defined as "the science of distribution and determinants of information in an electronic medium, specifically the Internet, or in a population, with the ultimate aim to inform public health and public policy" [1]. The first official mention of infodemiology according to a search in PubMed (ie, baring the term on the title) was by Gunther Eysenbach in 2002 [2]. However, infodemiology studies (ie, 
assessment of health-related topics using web-based data [3]) can be traced all the way back to 1996. Two more studies in the 2000s use the term (PubMed): one in 2004, where the quality of hospitals' websites was assessed [4], and one in 2006, showing that flu data from Google correlated with influenza cases [5].

The large corpus of publications in infodemiology were present after 2009, with the first complete presentation and assessment of the subject being found in the scoping review of Bernardo et al [6] published with JMIR Publications - the main publisher of infodemiology and infoveillance studies.

Social media and search queries are the most popular sources for retrieving information from web-based sources. The use of social media is constantly expanding [7], with more users and including more features. Search query data is also of significant value, as they take into account the revealed and not the stated users' preferences [8,9], but methodology should be designed with caution to ensure the validity of the results [10].

Popular social media data sources in infodemiology include Twitter [11-17], Facebook [18-22], and Instagram [23,24]. Queries from search engines are mostly retrieved by Google Trends [25-32], as well as Yandex [33-35], Baidu [36,37], Bing [38], Yahoo [39], and Daum [40,41]. Other popular sources include websites and platforms [42-45]; blogs, forums, and online communities [46-52]; and, what has received attention lately, mobile apps of certain health categories (eg, asthma [53] and heart failure self-care management [54]). Significant focus has been shown in combining two or more sources such as Facebook and Instagram [55], Facebook and Twitter Posts [56], US newspaper media and Facebook [57], and Google and Wikipedia [58].

The use of web-based sources offers an assessment of real-time information, whether it is from Twitter, Google, or other social media and search queries. For health data retrieved through traditional methods such as registries, questionnaires, or surveys, analysis and assessment can take time to perform. Thus, nowcasting using said methods is not trivial. However, web-based (real time) data has been shown to significantly contribute to the analysis and forecasting of certain diseases, outbreaks, and epidemics.

Therefore, this specific part of health informatics has benefitted from infodemiology. In particular, one of the most studied diseases is influenza, and several data sources have been employed to predict and assess flu-related topics [39,40,59-76]. Epidemics and infectious diseases that have been analyzed and assessed using infodemiology and infoveillance approaches include HIV/AIDS [77-79], measles [80-83], and the Zika virus [84-87].

Infodemiology topics have also been the subject of research for several reviews on various topics like curable sexually transmitted diseases (STDs) [88] and mental health disorders [89], and for data sources like search queries, social media [6], mobile phone apps [90], Twitter [91], and Google Trends [92].

Infodemiology has contributed to health assessment with the analysis of a range of topics. In specific, popular categories in the field of infodemiology and infoveillance include drugs [39,93,94], marijuana [95-97], depression and suicide [98-108], smoking and tobacco [109-116], electronic cigarettes (e-cigarettes) [117-126], and hookahs [127-130]. As far as chronic diseases are concerned, the assessment of diabetes [131-136] and multiple sclerosis [137,138] has benefitted from infodemiology and infoveillance studies. Other topics include breast cancer [139-142]; fitness and diet [143-146]; health care performance, evaluation, and dissemination [147,148]; and human papillomavirus (HPV) [149-154].

This review aims to update and expand the 2013 scoping review of Bernardo et al [6]. The authors of said review provided a well-structured outline of how infodemiology was employed in health informatics research up to that point, but as is evident, the large corpus of studies in the field have been published within the last couple of years. This update on the subject is important in identifying how infodemiology has contributed to health informatics over the past decade compared with traditional surveillance methods, the main web sources used, and the individual health categories and topics that have been explored. Apart from identifying the "metrics" of infodemiology studies (ie, numer of publications, thematic topics, journals and publishers, and data sources), this review aims to identify the advantages, disadvantages, and value and validity of infodemiology and infoveillance.

\section{Methods}

To select the publications in the fields of infodemiology and infoveillance, the Preferred Reporting Items for Systematic Reviews and Meta-Analyses (PRISMA) Extension for Scoping Reviews $[155,156]$ were followed. The procedure is depicted in the PRISMA flow diagram in Figure 1.

In the JMIR Publications database, all papers from the two relevant electronic collections (e-collections) were retrieved: 225 documents from the "Infodemiology and Infoveillance" [157] e-collection in the Journal of Medical Internet Research and 185 from the "Infodemiology, Infoveillance, and Digital Disease Surveillance" [158] e-collection in JMIR Public Health and Surveillance. After removing the duplicates and 2 documents for article type eligibility, 227 documents were extracted in total. Next, 66 documents were handpicked from the JMIR publications database based on searches of data sources (ie, "Twitter," "Google Trends," and "Google Flu Trends"). After 10 documents were excluded based on article type, a total of 56 documents were handpicked from the JMIR database. 
Figure 1. Preferred Reporting Items for Systematic Reviews and Meta-Analyses diagram for selecting the publications from JMIR, PubMed, and Scopus.

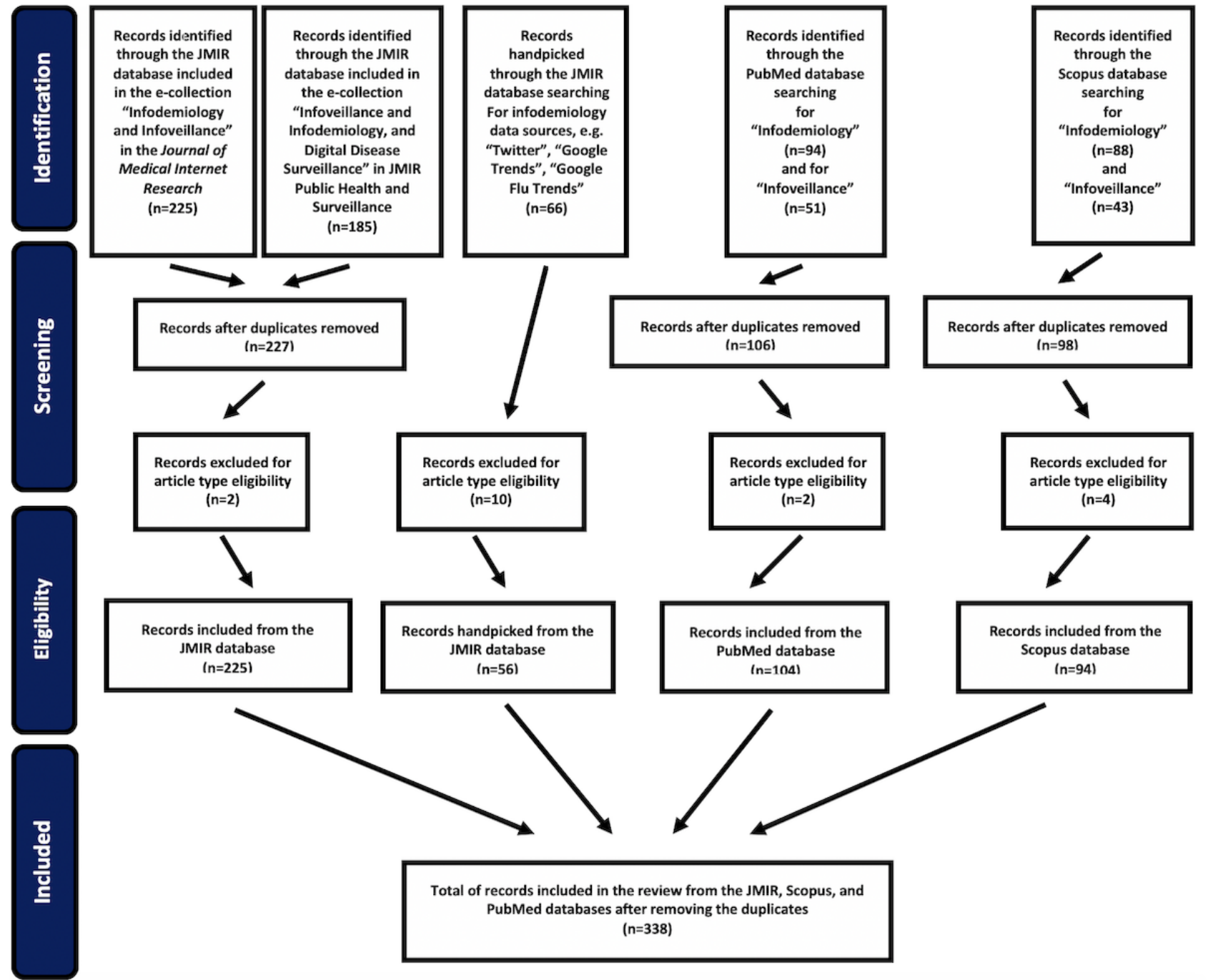

Next, the term "infodemiology" was searched for in the PubMed database from January 1, 2009, to December 31, 2018, in the search field "Title-Abstract." The search returned 94 documents. The term "infoveillance" was then entered for the same period and in the same field, and the search returned 51 documents. The duplicates were 39 in total, and 2 documents were excluded based on article type; a total of 104 documents were extracted from the PubMed database. The terms "infodemiology" and "infoveillance" were then independently searched for in the Scopus database in the "Article title, Abstract, Keywords" field for the full years 2009-2018. The search returned 88 and 43 documents, respectively (ie, a total of 131). After removing 33 duplicates and 4 documents for article type criteria, a total of 94 documents were extracted from the Scopus database.

Overall, all studies that included the terms "infodemiology" or "infoveillance" in the "Title/Abstract" field in PubMed up to December 2018 and all studies including the terms "infodemiology" or "infoveillance" in the "Article title, Abstract, Keywords" field up to 2018 in Scopus were selected. For JMIR, all articles in the two relevant e-collections, as well as the articles derived by the individual data source searches, were included in this review. Articles were only excluded based on article type eligibility (eg, correction, erratum). After removing the duplicates from the JMIR, PubMed, and Scopus databases, the total extracted documents from all databases were 338 .

\section{Results}

Table A1 in Multimedia Appendix 1 consists of the 338 selected publications included in this review, and shows the authors' names, publication year, the title, and the journal used for the analysis. Figure 2 depicts the number of publications by year from 2009 to 2018.

The number of publications in the subject is increasing every year, with 2018 featuring more than one-fourth of the 338 total publications $(n=89,26.3 \%)$, and the publications from 2017 and 2018 combined accounted for more than half $(n=171$, $50.6 \%$ ) of the total number of publications in the past decade. 
Figure 2. Number of publications in infodemiology and infoveillance by year (2009-2018).

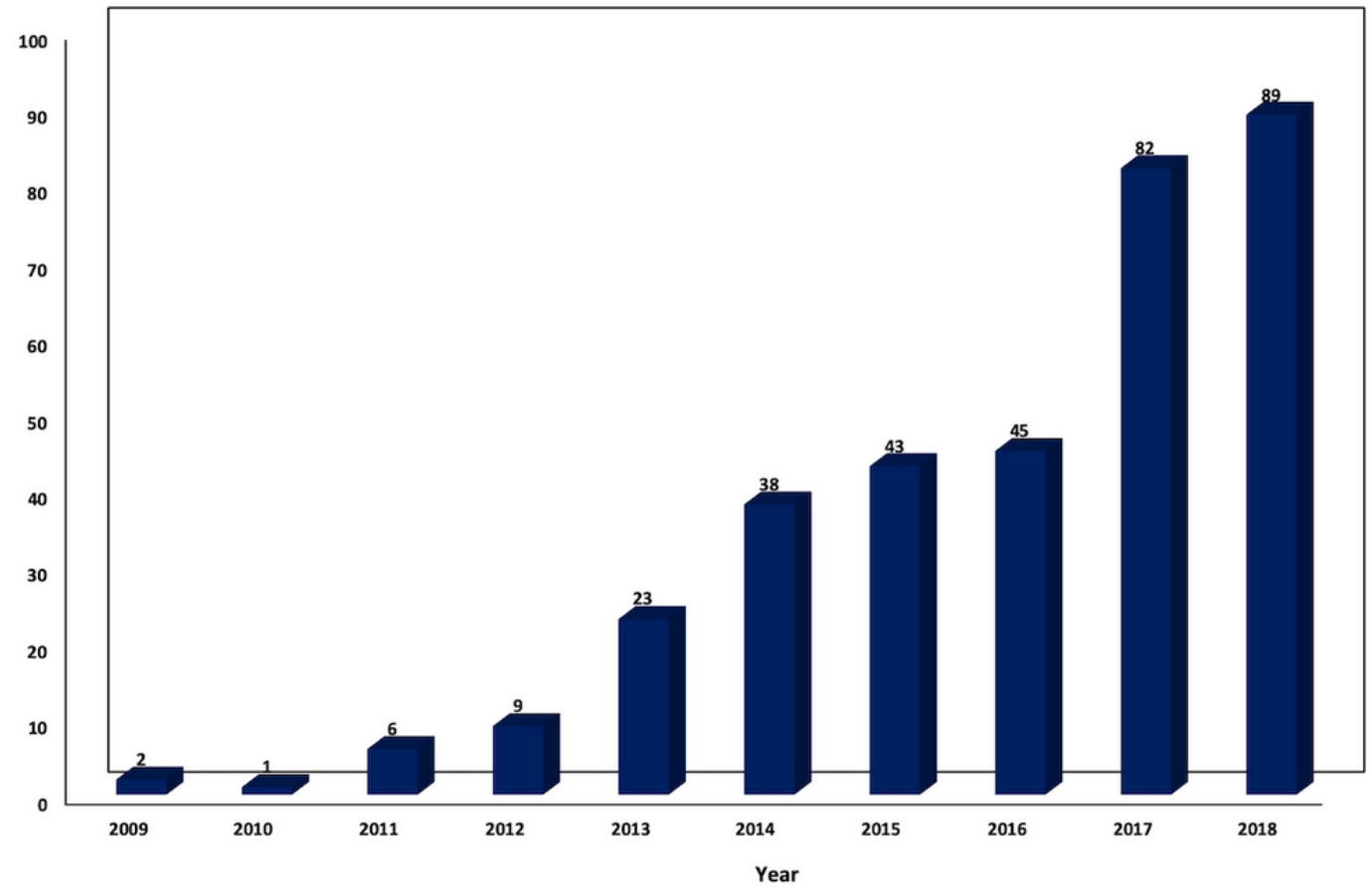

The 338 extracted studies were published in 57 journals in total. The vast majority of the studies in infodemiology and infoveillance were published with JMIR Publications $(n=282$, $83.4 \%$ ). Specifically, the Journal of Medical Internet Research features almost half of the publications $(n=168,49.7 \%)$, and JMIR Public Health and Surveillance features almost one-fourth of the examined studies $(\mathrm{n}=74,21.9 \%)$.

Figure 3 consists of the numbers of publications per journal with $>2$ publications on the subject.
Journals that have published more than 1 paper in the subject included JMIR Mental Health ( $\mathrm{n}=9$ ), JMIR Research Protocols $(n=7)$, JMIR Diabetes ( $n=4)$, JMIR Cancer $(n=3)$, JMIR Medical Informatics $(n=3)$, JMIR Pediatrics and Parenting $(n=3)$, the Journal of Big Data $(n=2)$, and the Interactive Journal of Medical Research $(n=2)$.

Table A2 of Multimedia Appendix 1 consists of the 338 publications categorized by data source employed. Figure 4 depicts the popularity of the examined data sources in terms of number of publications (some publications employed more than one data source).

Figure 3. Number of publications in infodemiology and infoveillance by journal (2009-2018). IEEE: Institute of Electrical and Electronics Engineers; JPH: JMIR Public Health and Surveillance.

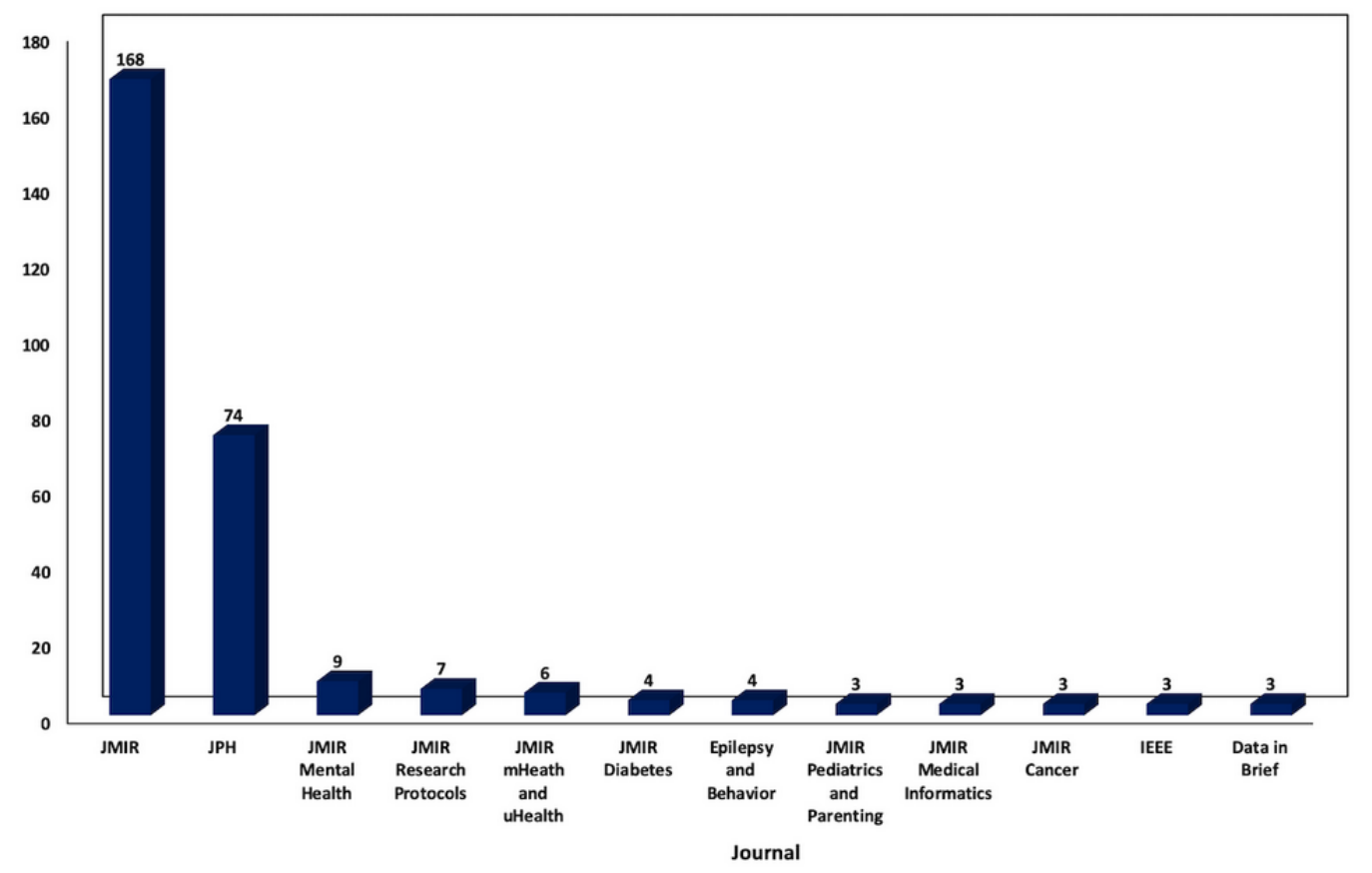


Figure 4. Number of publications by data source (2009-2018).

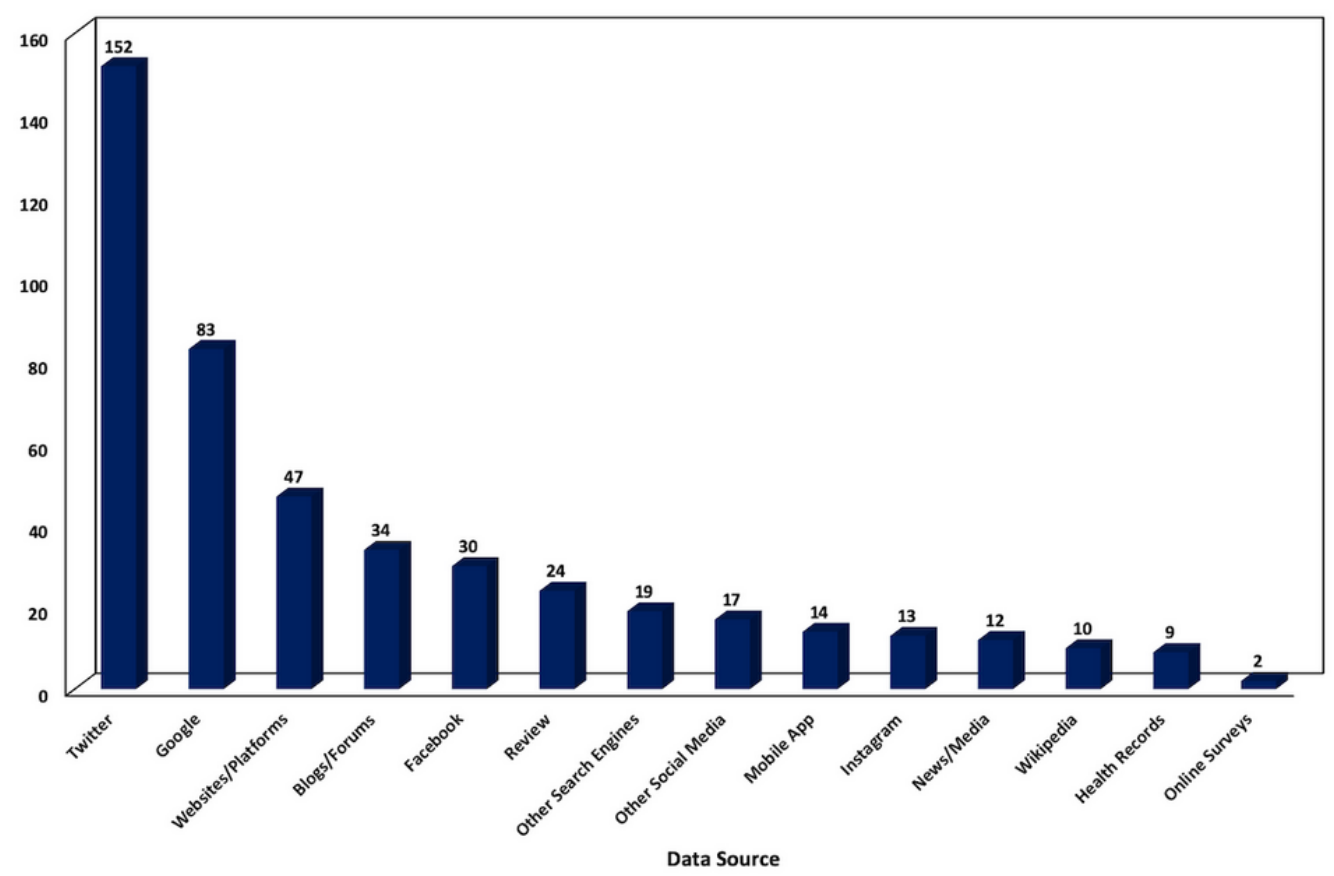

Of the 338 publications, the most popular source was Twitter with $45.0 \%(n=152)$ and is continuously gaining popularity. Google sources were in second place with $24.6 \% \quad(n=83)$, followed by websites and platforms with $13.9 \%(n=47)$, blogs and forums with $10.1 \%(n=34)$, Facebook with $8.9 \%(n=30)$, and other search engines with $5.6 \%(\mathrm{n}=19)$. The Google category consisted mainly of publications using Google Trends; although, the following Google tools have also been identified as main data sources in several publications: Google Flu Trends $(n=6)$, Google Analytics ( $n=2)$, Google Insights $(n=2)$, Google Correlate $(n=1)$, Google Health $(n=1)$, Google News $(n=1)$, Google AdWords ( $n=1)$, Google Video ( $n=1)$, and Google Blog Search $(n=1)$.

The "other search engines" category consists of Bing $(n=7)$, Baidu $(n=4)$, Yandex $(n=4)$, Daum $(n=2)$, and Yahoo $(n=3)$, and the "other social media" category consists of YouTube $(n=5)$, Yelp $(n=5)$, Google+ $(n=4)$, Foursquare $(n=1)$, SoundCloud ( $\mathrm{n}=1)$, Tumblr $(\mathrm{n}=1)$, Pinterest $(\mathrm{n}=1)$, and MySpace $(n=1)$. Yahoo answers $(n=2)$ was included in the blogs, forums, and communities category.

Although many health topics have been examined in infodemiology and infoveillance, some are significantly more popular. Figure 5 depicts the general categories in terms of number of publications, while Figure A1 of Multimedia Appendix 2 consists of the pie charts of their subcategories. All individual topics and subtopics identified in this review by number of publications can be found in Table A1 of Multimedia Appendix 2.

In the 338 publications examined in this review, the most popular subjects were conditions and diseases with $17.2 \%$ $(\mathrm{n}=58)$ and epidemics and outbreaks with $15.7 \% \quad(\mathrm{n}=53)$, followed by health care with $11.5 \%(\mathrm{n}=39)$, drugs with $10.4 \%$ $(\mathrm{n}=35)$, smoking and alcohol with $8.6 \%(\mathrm{n}=29)$, and mental health with $8.3 \%(n=28)$. Infectious diseases with $8.0 \%(n=27)$ and cancer with $6.8 \%(\mathrm{n}=23)$ were also featured in several publications. The categories of diet and fitness with $4.1 \%(n=14)$ and mother and child with $2.7 \%$ (9) were less popular. 
Figure 5. Health categories by number of publications (2009-2018).

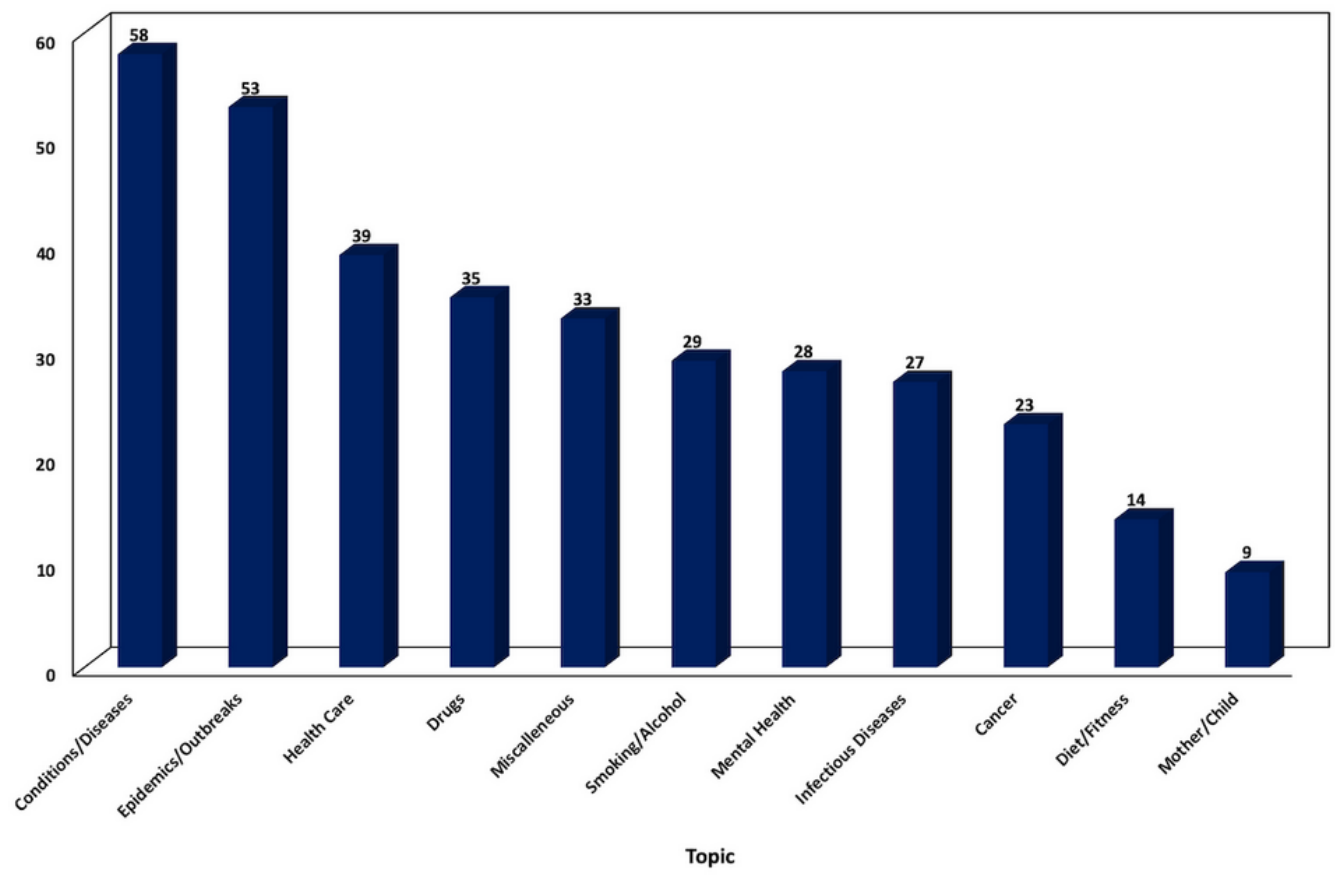

\section{Discussion}

\section{Principal Findings}

In this scoping review, the most popular web-based data source as well as the most studied health categories in infodemiology and infoveillance were identified through a systematic search of the existing literature.

\section{Time Line and Journals}

Based on the results, the use of web-based data in health informatics is significantly increasing year by year, with half of the publications from 2009 to 2018 being in the last couple of years. The JMIR Publications database is the most significant contributor in terms of the number of publications on the subject $(n=282 / 338,83.4 \%)$, especially given that the most significant infodemiology-oriented journal (ie, JMIR Public Health and Surveillance) is published with JMIR Publications. The concept of infodemiology, introduced by Gunther Eysenbach in 2002, has been gaining significant recognition since its birth, and it is evident that it will play an even more significant role in health informatics in the years to come, especially as internet penetration increases along with the average age of the users.

\section{Data Sources and Tools}

Figure 6 depicts the yearly changes in number of publications for the most popular data sources over the examined period. As evident, there was a significant increase in the use of web-data sources over the last couple of years, with Twitter in the lead in assessing health-related topics by health informatics researchers.
Despite the increasingly large number of users and the fact that Twitter is used significantly more than Google, Twitter has the limitation of not being universal. Its pros include that it is an outlet for official reports and news (eg, governmental, politicians), but a significant con is that it is not used by all; furthermore, not everyone interacts on the site (ie, tweets or retweets). The analysis of internet search traffic data-mainly from Google but from other search engines as well (eg, Bing, Yahoo)-is more universal in the sense that internet penetration has increased to a point where the large majority of people have access to and use the internet and searching for keywords in search engines is the most used internet feature. Apart from this, it also ensures anonymity, deeming it more reliable, as it uses the revealed and not the stated users' preferences. However, the choosing of the keywords (queries) as well as the methodology for selecting the retrieved data is much more complicated than with Twitter. In addition, more than one search engine exists, and thus, not all queries (data) on the respective selected topic can be retrieved.

On the other hand, there is a significant rise in the percentage of publications in the last couple of years using data from other social media such as Facebook and Instagram. This could be showing that younger internet users' preferences in the use of social media may be revealing a trend of said platforms over original search queries and websites. Researchers in this field should closely follow any potential shifts in internet use, along with the correspondence and age of users, to ensure-to the point that is possible with web-based data-that the sample is representative and the research aims to change along with what is trending. The latter is crucial for infodemiology research to continue to be valid, and it should be given significant focus. 
Figure 6. Yearly changes in number of publications for the most popular data sources (2009-2018).

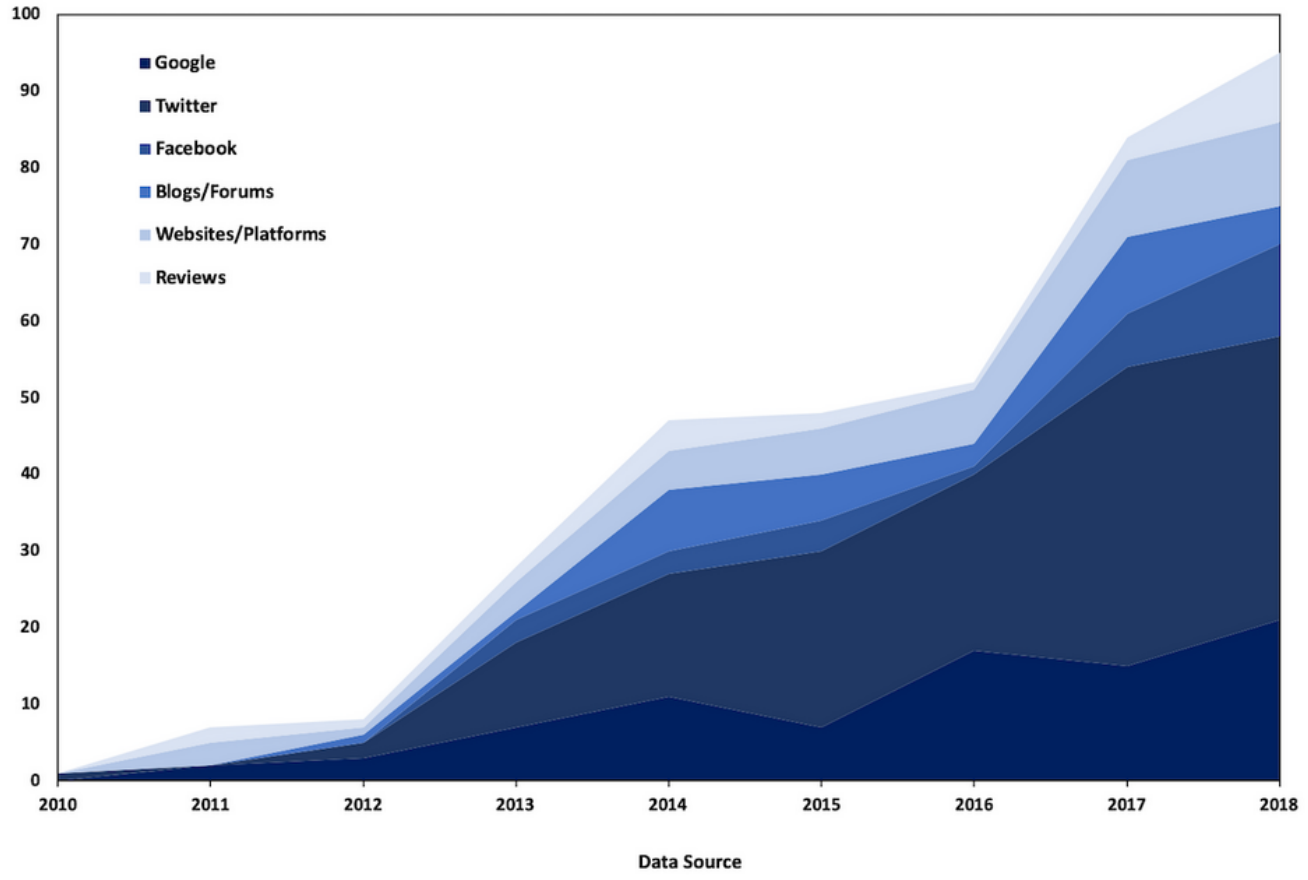

\section{Health Topics}

As is evident, there is a wide variety of topics that have been studied up to this point. The most popular topics identified in this review were illegal drugs, breast cancer, smoking, fitness, HIV/AIDS, depression, diabetes, influenza, HPV, multiple sclerosis, Zika virus, suicide, STDs, and e-cigarettes, and significant attention has been given to the evaluation of health care such as hospital ratings and patients' experiences and health topics' and medical institutions' dissemination strategies.

Approaches include nowcasting epidemics and outbreaks, surveillance of infectious diseases, assessment of chronic conditions, and basically everything traditional surveillance methods have aimed to do. Thus, the results of this review show not only the increasing popularity of web-based data but also their significant contribution to the existing literature, as well as the value of infodemiology in health informatics.

\section{Advantages and Disadvantages}

The difference in using web-based data-infodemiology's main advantage - is that it tackles the issue of traditional surveillance methods not providing real time assessments. Even in the health sector, where data are generally available compared to other topics, the gathering, assessing, and publishing of health data can sometimes take years to process. This is less of an issue for topics such as chronic diseases that are not infectious, but it makes the assessment and forecasting of epidemics and outbreaks much more complicated.

Another significant advantage of infoveillance compared to traditional surveillance methods is the anonymity that web-based data offers. Online search traffic data are completely anonymous, and in most social media and forums, an individual has the option of anonymity. In this way, data retrieved from said sources are the revealed and not the stated preferences, which can be a plus for sensitive topics such as AIDS or STDs.
Despite the many advantages that web-based data sources have to offer, several limitations have been identified in the use of infodemiology sources. The main disadvantage of using web-based sources is that the data can be affected by sudden incidents or events, which, especially in nowcasting or when the number of observations is low, could provide biased results. Similarly, the sample cannot be shown to be representative, especially in the assessment of online search traffic data; although, this is less of an issue as internet penetration increases.

With real time data that can be retrieved from web sources, disease surveillance has become much faster than with traditional methods, and web sources also have the benefit of assessing large populations, which contrasts with most traditional methods that are based on data retrieved from significantly smaller groups, such as with interviews or questionnaires. Overall, what health informatics should aim toward in the future is to combine web-data sources with traditional data assessment to provide an even more complete assessment.

\section{Limitations}

The main limitation of this scoping review was that not all infodemiology papers could be included. Though the selection of publications for this work was thorough and followed the guidelines for proper selection and included the main outlets for infodemiology papers (ie, JMIR Publications and PubMed), some publications may have been left out; a limitation that all reviews have. Specifically, articles using the two most popular infodemiology sources (ie, Twitter and Google) were only searched for in the JMIR database. Studies using, for example, Google Trends and Twitter constitute a large body of the relevant literature, and a significant number of said studies were not included as they did not use the specific searched for terms (ie, infodemiology and infoveillance); the latter being the main difference from the original Bernardo et al [6] scoping review. 
However, despite the possible reduced number of included publications that use infodemiology and infoveillance sources but not the infodemiology or infoveillance terms, as JMIR is the main outlet for such themed publications, this scoping review gives a valuable qualitative and quantitative overview of how the concept has progressed over the last decade, as well as identifying the main sources and topics that have been used and assessed. Future work should focus on expanding the present results, as well as recording infodemiology papers based on tools used. As the search by source yields many results, focus should be given to future systematic reviews on the subject by source as has been done, for example, for the use of Google Trends [92].

\section{Conclusions}

Using web-based sources in epidemiology and disease surveillance has shown to be valuable and valid over the past decade, and the results of this scoping review clearly point to this direction. Data sources cover a wide variety of tools, social media, platforms, websites, blogs, and search engines, and the topics that are the most studied vary from chronic disease prevalence to nowcasting epidemics. Infodemiology and infoveillance tackle several of the issues that arise with traditional assessment methods, and, as internet penetration increases, employing web data sources for health assessment could be the future in health informatics.

\section{Conflicts of Interest}

None declared.

\section{Multimedia Appendix 1}

Infodemiology and infoveillance publications from JMIR, Scopus, and PubMed (2009-2018).

[PDF File (Adobe PDF File), 1420 KB-Multimedia Appendix 1]

\section{Multimedia Appendix 2}

Topics and subtopics (\#publications) in infodemiology and infoveillance (2009- 2018). [PDF File (Adobe PDF File), 1430 KB-Multimedia Appendix 2]

\section{References}

1. Eysenbach G. Infodemiology and infoveillance: framework for an emerging set of public health informatics methods to analyze search, communication and publication behavior on the Internet. J Med Internet Res 2009 Mar 27;11(1):e11. [doi: 10.2196/jmir.1157] [Medline: 19329408]

2. Eysenbach G. Infodemiology: the epidemiology of (mis)information. The American Journal of Medicine 2002 Dec;113(9):763-765. [doi: 10.1016/s0002-9343(02)01473-0]

3. Eysenbach G. Infodemiology and infoveillance tracking online health information and cyberbehavior for public health. Am J Prev Med 2011 May;40(5 Suppl 2):S154-S158. [doi: 10.1016/j.amepre.2011.02.006] [Medline: 21521589]

4. Kind T, Wheeler KL, Robinson B, Cabana MD. Do the leading children's hospitals have quality web sites? A description of children's hospital web sites. J Med Internet Res 2004 Jun 25;6(2):e20. [doi: 10.2196/jmir.6.2.e20] [Medline: 15249269]

5. Eysenbach G. Infodemiology: tracking flu-related searches on the web for syndromic surveillance. AMIA Annu Symp Proc 2006:244-248 [FREE Full text] [Medline: 17238340]

6. Bernardo TM, Rajic A, Young I, Robiadek K, Pham MT, Funk JA. Scoping review on search queries and social media for disease surveillance: a chronology of innovation. J Med Internet Res 2013 Jul 18;15(7):e147. [doi: 10.2196/jmir.2740] [Medline: 23896182]

7. Pew Research Center. Social Media Fact Sheet URL: https://www.pewinternet.org/fact-sheet/social-media/ [accessed 2019-09-09]

8. Mavragani A, Tsagarakis KP. Predicting referendum results in the Big Data Era. J Big Data 2019 Jan 14;6(1):e. [doi: 10.1186/s40537-018-0166-z]

9. Mavragani A, Tsagarakis KP. YES or NO: predicting the 2015 GReferendum results using Google Trends. Technological Forecasting and Social Change 2016 Aug;109:1-5. [doi: 10.1016/j.techfore.2016.04.028]

10. Mavragani A, Ochoa G. Google Trends in infodemiology and infoveillance: methodology framework. JMIR Public Health Surveill 2019 May 29;5(2):e13439. [doi: 10.2196/13439] [Medline: 31144671]

11. Bian J, Zhao Y, Salloum RG, Guo Y, Wang M, Prosperi M, et al. Using social media data to understand the impact of promotional information on laypeople's discussions: a case study of lynch syndrome. J Med Internet Res 2017 Dec 13;19(12):e414. [doi: 10.2196/jmir.9266] [Medline: 29237586]

12. Chen T, Dredze M. Vaccine images on Twitter: analysis of what images are shared. J Med Internet Res 2018 Apr 03;20(4):e130. [doi: 10.2196/jmir.8221] [Medline: 29615386]

13. Hswen Y, Naslund JA, Brownstein JS, Hawkins JB. Monitoring online discussions about suicide among Twitter users with schizophrenia: exploratory study. JMIR Ment Health 2018 Dec 13;5(4):e11483. [doi: 10.2196/11483] [Medline: 30545811] 
14. Odlum M, Yoon S, Broadwell P, Brewer R, Kuang D. How Twitter can support the HIV/AIDS response to achieve the 2030 eradication goal: in-depth thematic analysis of World AIDS Day tweets. JMIR Public Health Surveill 2018 Nov 22;4(4):e10262. [doi: 10.2196/10262] [Medline: 30467102]

15. Chen S, Xu Q, Buchenberger J, Bagavathi A, Fair G, Shaikh S, et al. Dynamics of health agency response and public engagement in public health emergency: a case study of CDC tweeting patterns during the 2016 Zika epidemic. JMIR Public Health Surveill 2018 Nov 22;4(4):e10827. [doi: 10.2196/10827] [Medline: 30467106]

16. Wakamiya S, Kawai Y, Aramaki E. Twitter-based influenza detection after flu peak via tweets with indirect information: text mining study. JMIR Public Health Surveill 2018 Sep 25;4(3):e65. [doi: 10.2196/publichealth.8627] [Medline: 30274968]

17. Tufts C, Polsky D, Volpp KG, Groeneveld PW, Ungar L, Merchant RM, et al. Characterizing tweet volume and content about common health conditions across Pennsylvania: retrospective analysis. JMIR Public Health Surveill 2018 Dec 06;4(4):e10834. [doi: 10.2196/10834] [Medline: 30522989]

18. Saha K, Weber I, Birnbaum ML, De Choudhury M. Characterizing awareness of schizophrenia among Facebook users by leveraging Facebook advertisement estimates. J Med Internet Res 2017 May 08;19(5):e156. [doi: 10.2196/jmir.6815] [Medline: 28483739]

19. Smith RJ, Crutchley P, Schwartz HA, Ungar L, Shofer F, Padrez KA, et al. Variations in Facebook posting patterns across validated patient health conditions: a prospective cohort study. J Med Internet Res 2017 Jan 06;19(1):e7. [doi:

10.2196/jmir.6486] [Medline: 28062392]

20. Gittelman S, Lange V, Gotway Crawford CA, Okoro CA, Lieb E, Dhingra SS, et al. A new source of data for public health surveillance: Facebook likes. J Med Internet Res 2015 Apr 20;17(4):e98. [doi: 10.2196/jmir.3970] [Medline: 25895907]

21. Keller MS, Park HJ, Cunningham ME, Fouladian JE, Chen M, Spiegel BMR. Public perceptions regarding use of virtual reality in health care: a social media content analysis using Facebook. J Med Internet Res 2017 Dec 19;19(12):e419. [doi: 10.2196/jmir.7467] [Medline: 29258975]

22. Mejova Y, Weber I, Fernandez-Luque L. Online health monitoring using Facebook advertisement audience estimates in the United States: evaluation study. JMIR Public Health Surveill 2018 Mar 28;4(1):e30. [doi: 10.2196/publichealth.7217] [Medline: 29592849]

23. Cherian R, Westbrook M, Ramo D, Sarkar U. Representations of codeine misuse on Instagram: content analysis. JMIR Public Health Surveill 2018 Mar 20;4(1):e22. [doi: 10.2196/publichealth.8144] [Medline: 29559422]

24. Muralidhara S, Paul MJ. \#Healthy Selfies: exploration of health topics on Instagram. JMIR Public Health Surveill 2018 Jun 29;4(2):e10150. [doi: 10.2196/10150] [Medline: 29959106]

25. Phillips CA, Barz Leahy A, Li Y, Schapira MM, Bailey LC, Merchant RM. Relationship between state-level Google online search volume and cancer incidence in the United States: retrospective study. J Med Internet Res 2018 Jan 08;20(1):e6. [doi: 10.2196/jmir.8870] [Medline: 29311051]

26. Radin M, Sciascia S. Infodemiology of systemic lupus erythematous using Google Trends. Lupus 2017 Jul;26(8):886-889. [doi: 10.1177/0961203317691372] [Medline: 28162030]

27. Seidl S, Schuster B, Rüth M, Biedermann T, Zink A. What do Germans want to know about skin cancer? a nationwide Google search analysis from 2013 to 2017. J Med Internet Res 2018 May 02;20(5):e10327. [doi: 10.2196/10327] [Medline: 29698213]

28. Wang H, Chen D, Yu H, Chen Y. Forecasting the incidence of dementia and dementia-related outpatient visits with Google Trends: evidence from Taiwan. J Med Internet Res 2015 Nov 19;17(11):e264. [doi: 10.2196/jmir.4516] [Medline: 26586281]

29. Berlinberg EJ, Deiner MS, Porco TC, Acharya NR. Monitoring interest in herpes zoster vaccination: analysis of Google search data. JMIR Public Health Surveill 2018 May 02;4(2):e10180. [doi: 10.2196/10180] [Medline: 29720364]

30. Mavragani A, Ochoa G. Infoveillance of infectious diseases in USA: STDs, tuberculosis, and hepatitis. J Big Data 2018 Sep 6;5(1):30. [doi: 10.1186/s40537-018-0140-9]

31. Mavragani A, Sampri A, Sypsa K, Tsagarakis KP. Integrating smart health in the US health care system: infodemiology study of asthma monitoring in the Google Era. JMIR Public Health Surveill 2018 Mar 12;4(1):e24. [doi:

10.2196/publichealth.8726] [Medline: 29530839]

32. Zhang Z, Zheng X, Zeng DD, Leischow SJ. Tracking dabbing using search query surveillance: a case study in the United States. J Med Internet Res 2016 Sep 16;18(9):e252. [doi: 10.2196/jmir.5802] [Medline: 27637361]

33. Zheluk A, Gillespie JA, Quinn C. Searching for truth: internet search patterns as a method of investigating online responses to a Russian illicit drug policy debate. J Med Internet Res 2012 Dec 13;14(6):e165. [doi: 10.2196/jmir.2270] [Medline: 23238600]

34. Zheluk A, Quinn C, Meylakhs P. Internet search and krokodil in the Russian Federation: an infoveillance study. J Med Internet Res 2014 Sep 18;16(9):e212. [doi: 10.2196/jmir.3203] [Medline: 25236385]

35. Domnich A, Arbuzova EK, Signori A, Amicizia D, Panatto D, Gasparini R. Demand-based web surveillance of sexually transmitted infections in Russia. Int J Public Health 2014 Oct;59(5):841-849. [doi: 10.1007/s00038-014-0581-7] [Medline: 25012799]

36. Agarwal V, Zhang L, Zhu J, Fang S, Cheng T, Hong C, et al. Impact of predicting health care utilization via web search behavior: a data-driven analysis. J Med Internet Res 2016 Sep 21;18(9):e251. [doi: 10.2196/jmir.6240] [Medline: 27655225] 
37. Yang H, Li S, Sun L, Zhang X, Hou J, Wang Y. Effects of the ambient fine particulate matter on public awareness of lung cancer risk in China: evidence from the internet-based big data platform. JMIR Public Health Surveill 2017 Oct 03;3(4):e64. [doi: 10.2196/publichealth.8078] [Medline: 28974484]

38. Cartwright AF, Karunaratne M, Barr-Walker J, Johns NE, Upadhyay UD. Identifying national availability of abortion care and distance from major US cities: systematic online search. J Med Internet Res 2018 May 14;20(5):e186. [doi: 10.2196/jmir.9717] [Medline: 29759954]

39. Yom-Tov E, Gabrilovich E. Postmarket drug surveillance without trial costs: discovery of adverse drug reactions through large-scale analysis of web search queries. J Med Internet Res 2013 Jun 18;15(6):e124. [doi: 10.2196/jmir.2614] [Medline: 23778053]

40. Seo D, Jo M, Sohn CH, Shin S, Lee J, Yu M, et al. Cumulative query method for influenza surveillance using search engine data. J Med Internet Res 2014 Dec 16;16(12):e289. [doi: 10.2196/jmir.3680] [Medline: 25517353]

41. Woo H, Cho Y, Shim E, Lee J, Lee C, Kim SH. Estimating influenza outbreaks using both search engine query data and social media data in South Korea. J Med Internet Res 2016 Jul 04;18(7):e177. [doi: 10.2196/jmir.4955] [Medline: 27377323]

42. Leung R, Guo H, Pan X. Social media users' perception of telemedicine and mHealth in China: exploratory study. JMIR Mhealth Uhealth 2018 Sep 25;6(9):e181. [doi: 10.2196/mhealth.7623] [Medline: 30274969 ]

43. Li Q, Wang C, Liu R, Wang L, Zeng DD, Leischow SJ. Understanding users' vaping experiences from social media: initial study using sentiment opinion summarization techniques. J Med Internet Res 2018 Aug 15;20(8):e252. [doi: 10.2196/jmir.9373] [Medline: 30111530]

44. Sadah SA, Shahbazi M, Wiley MT, Hristidis V. A study of the demographics of web-based health-related social media users. J Med Internet Res 2015 Aug 06;17(8):e194. [doi: 10.2196/jmir.4308] [Medline: 26250986]

45. Sadah SA, Shahbazi M, Wiley MT, Hristidis V. Demographic-based content analysis of web-based health-related social media. J Med Internet Res 2016 Jun 13;18(6):e148. [doi: 10.2196/jmir.5327] [Medline: 27296242]

46. Abbe A, Falissard B. Stopping antidepressants and anxiolytics as major concerns reported in online health communities: a text mining approach. JMIR Ment Health 2017 Oct 23;4(4):e48. [doi: 10.2196/mental.7797] [Medline: 29061554]

47. Abdellaoui R, Schück S, Texier N, Burgun A. Filtering entities to optimize identification of adverse drug reaction from social media: how can the number of words between entities in the messages help? JMIR Public Health Surveill 2017 Jun 22;3(2):e36. [doi: 10.2196/publichealth.6577] [Medline: 28642212]

48. Abdellaoui R, Foulquié P, Texier N, Faviez C, Burgun A, Schück S. Detection of cases of noncompliance to drug treatment in patient forum posts: topic model approach. J Med Internet Res 2018 Mar 14;20(3):e85. [doi: 10.2196/jmir.9222] [Medline: 29540337]

49. Dyson MP, Newton AS, Shave K, Featherstone RM, Thomson D, Wingert A, et al. Social media for the dissemination of Cochrane child health evidence: evaluation study. J Med Internet Res 2017 Sep 01;19(9):e308. [doi: 10.2196/jmir.7819] [Medline: 28864427]

50. Jung Y, Hur C, Jung D, Kim M. Identifying key hospital service quality factors in online health communities. J Med Internet Res 2015 Apr 07;17(4):e90. [doi: 10.2196/jmir.3646] [Medline: 25855612]

51. Koh S, Gordon AS, Wienberg C, Sood SO, Morley S, Burke DM. Stroke experiences in weblogs: a feasibility study of sex differences. J Med Internet Res 2014 Mar 19;16(3):e84. [doi: 10.2196/jmir.2838] [Medline: 24647327]

52. Konheim-Kalkstein YL, Miron-Shatz T, Israel LJ. How women evaluate birth challenges: analysis of web-based birth stories. JMIR Pediatr Parent 2018 Dec 18;1(2):e12206. [doi: 10.2196/12206] [Medline: $\underline{\text { 31518300] }}$

53. Tinschert P, Jakob R, Barata F, Kramer J, Kowatsch T. The potential of mobile apps for improving asthma self-management: a review of publicly available and well-adopted asthma apps. JMIR Mhealth Uhealth 2017 Aug 02;5(8):e113. [doi: 10.2196/mhealth.7177] [Medline: 28768606]

54. Athilingam P, Jenkins B. Mobile phone apps to support heart failure self-care management: integrative review. JMIR Cardio 2018 May 02;2(1):e10057. [doi: 10.2196/10057] [Medline: 31758762]

55. Hendriks H, Van den Putte B, Gebhardt WA, Moreno MA. Social drinking on social media: content analysis of the social aspects of alcohol-related posts on Facebook and Instagram. J Med Internet Res 2018 Jun 22;20(6):e226. [doi: 10.2196/jmir.9355] [Medline: 29934290]

56. Roccetti M, Marfia G, Salomoni P, Prandi C, Zagari RM, Gningaye Kengni FL, et al. Attitudes of Crohn's disease patients: infodemiology case study and sentiment analysis of Facebook and Twitter posts. JMIR Public Health Surveill 2017 Aug 09;3(3):e51. [doi: 10.2196/publichealth.7004] [Medline: 28793981]

57. Manchaiah V, Ratinaud P, Andersson G. Representation of tinnitus in the US newspaper media and in Facebook pages: cross-sectional analysis of secondary data. Interact J Med Res 2018 May 08;7(1):e9. [doi: 10.2196/ijmr.9065] [Medline: 29739734]

58. Sciascia S, Radin M. What can Google and Wikipedia can tell us about a disease? Big Data trends analysis in Systemic Lupus Erythematosus. Int J Med Inform 2017 Nov;107:65-69. [doi: 10.1016/j.ijmedinf.2017.09.002] [Medline: 29029693]

59. Sharpe JD, Hopkins RS, Cook RL, Striley CW. Evaluating Google, Twitter, and Wikipedia as tools for influenza surveillance using bayesian change point analysis: a comparative analysis. JMIR Public Health Surveill 2016 Oct 20;2(2):e161. [doi: 10.2196/publichealth.5901] [Medline: 27765731] 
60. Timpka T, Spreco A, Dahlström Ö, Eriksson O, Gursky E, Ekberg J, et al. Performance of eHealth data sources in local influenza surveillance: a 5-year open cohort study. J Med Internet Res 2014 Apr 28;16(4):e116. [doi: 10.2196/jmir.3099] [Medline: 24776527]

61. Wagner M, Lampos V, Yom-Tov E, Pebody R, Cox IJ. Estimating the population impact of a new pediatric influenza vaccination program in England using social media content. J Med Internet Res 2017 Dec 21;19(12):e416. [doi: 10.2196/jmir.8184] [Medline: 29269339]

62. Aslam AA, Tsou M, Spitzberg BH, An L, Gawron JM, Gupta DK, et al. The reliability of tweets as a supplementary method of seasonal influenza surveillance. J Med Internet Res 2014 Nov 14;16(11):e250. [doi: 10.2196/jmir.3532] [Medline: 25406040]

63. Baltrusaitis K, Santillana M, Crawley AW, Chunara R, Smolinski M, Brownstein JS. Determinants of participants' follow-up and characterization of representativeness in Flu Near You, a participatory disease surveillance system. JMIR Public Health Surveill 2017 Apr 07;3(2):e18. [doi: 10.2196/publichealth.7304] [Medline: 28389417]

64. Broniatowski DA, Dredze M, Paul MJ, Dugas A. Using social media to perform local influenza surveillance in an inner-city hospital: a retrospective observational study. JMIR Public Health Surveill 2015;1(1):e5. [doi: 10.2196/publichealth.4472] [Medline: 27014744]

65. Chen B, Shao J, Liu K, Cai G, Jiang Z, Huang Y, et al. Does eating chicken feet with pickled peppers cause avian influenza? observational case study on Chinese social media during the avian influenza A (H7N9) outbreak. JMIR Public Health Surveill 2018 Mar 29;4(1):e32. [doi: 10.2196/publichealth.8198] [Medline: 29599109]

66. Gu H, Chen B, Zhu H, Jiang T, Wang X, Chen L, et al. Importance of Internet surveillance in public health emergency control and prevention: evidence from a digital epidemiologic study during avian influenza A H7N9 outbreaks. J Med Internet Res 2014 Jan 17;16(1):e20. [doi: 10.2196/jmir.2911] [Medline: 24440770]

67. Hill S, Mao J, Ungar L, Hennessy S, Leonard CE, Holmes J. Natural supplements for H1N1 influenza: retrospective observational infodemiology study of information and search activity on the Internet. J Med Internet Res 2011 May 10;13(2):e36. [doi: 10.2196/jmir.1722] [Medline: 21558062]

68. Kagashe I, Yan Z, Suheryani I. Enhancing seasonal influenza surveillance: topic analysis of widely used medicinal drugs using Twitter data. J Med Internet Res 2017 Sep 12;19(9):e315. [doi: 10.2196/jmir.7393] [Medline: 28899847]

69. Kandula S, Hsu D, Shaman J. Subregional nowcasts of seasonal influenza using search trends. J Med Internet Res 2017 Nov 06;19(11):e370. [doi: 10.2196/jmir.7486] [Medline: 29109069]

70. Klembczyk JJ, Jalalpour M, Levin S, Washington RE, Pines JM, Rothman RE, et al. Google Flu Trends spatial variability validated against emergency department influenza-related visits. J Med Internet Res 2016 Jun 28;18(6):e175. [doi: 10.2196/jmir.5585] [Medline: 27354313]

71. Lu FS, Hou S, Baltrusaitis K, Shah M, Leskovec J, Sosic R, et al. Accurate influenza monitoring and forecasting using novel internet data streams: a case study in the Boston Metropolis. JMIR Public Health Surveill 2018 Jan 09;4(1):e4. [doi: 10.2196/publichealth.8950] [Medline: 29317382]

72. Mao C, Wu X, Fu X, Di M, Yu Y, Yuan J, et al. An internet-based epidemiological investigation of the outbreak of H7N9 Avian influenza A in China since early 2013. J Med Internet Res 2014 Sep 25;16(9):e221. [doi: 10.2196/jmir.3763] [Medline: 25257217]

73. Pervaiz F, Pervaiz M, Abdur Rehman N, Saif U. FluBreaks: early epidemic detection from Google flu trends. J Med Internet Res 2012 Oct 04;14(5):e125. [doi: 10.2196/jmir.2102] [Medline: 23037553]

74. Poirier C, Lavenu A, Bertaud V, Campillo-Gimenez B, Chazard E, Cuggia M, et al. Real time influenza monitoring using hospital big data in combination with machine learning methods: comparison study. JMIR Public Health Surveill 2018 Dec 21;4(4):e11361. [doi: 10.2196/11361] [Medline: 30578212]

75. Samaras L, García-Barriocanal E, Sicilia M. Syndromic surveillance models using web data: the case of influenza in Greece and Italy using Google Trends. JMIR Public Health Surveill 2017 Nov 20;3(4):e90. [doi: 10.2196/publichealth.8015] [Medline: 29158208]

76. Santos JC, Matos S. Analysing Twitter and web queries for flu trend prediction. Theor Biol Med Model 2014 May 07;11 Suppl 1:S6 [FREE Full text] [doi: 10.1186/1742-4682-11-S1-S6] [Medline: 25077431]

77. Adrover C, Bodnar T, Huang Z, Telenti A, Salathé M. Identifying adverse effects of HIV drug treatment and associated sentiments using Twitter. JMIR Public Health Surveill 2015;1(2):e7. [doi: 10.2196/publichealth.4488] [Medline: 27227141]

78. Zheluk A, Quinn C, Hercz D, Gillespie JA. Internet search patterns of human immunodeficiency virus and the digital divide in the Russian Federation: infoveillance study. J Med Internet Res 2013 Nov 12;15(11):e256. [doi: 10.2196/jmir.2936] [Medline: 24220250]

79. Mavragani A, Ochoa G. Forecasting AIDS prevalence in the United States using online search traffic data. J Big Data 2018 May 19;5(1):5. [doi: 10.1186/s40537-018-0126-7]

80. Mollema L, Harmsen IA, Broekhuizen E, Clijnk R, De Melker H, Paulussen T, et al. Disease detection or public opinion reflection? Content analysis of tweets, other social media, and online newspapers during the measles outbreak in The Netherlands in 2013. J Med Internet Res 2015 May 26;17(5):e128. [doi: 10.2196/jmir.3863] [Medline: 26013683] 
81. Radzikowski J, Stefanidis A, Jacobsen KH, Croitoru A, Crooks A, Delamater PL. The measles vaccination narrative in Twitter: a quantitative analysis. JMIR Public Health Surveill 2016;2(1):e1. [doi: 10.2196/publichealth.5059] [Medline: 27227144]

82. Du J, Tang L, Xiang Y, Zhi D, Xu J, Song H, et al. Public perception analysis of Tweets during the 2015 measles outbreak: comparative study using convolutional neural network models. J Med Internet Res 2018 Jul 09;20(7):e236. [doi: 10.2196/jmir.9413] [Medline: 29986843]

83. Mavragani A, Ochoa G. The internet and the anti-vaccine movement: tracking the 2017 EU measles outbreak. BDCC 2018 Jan 16;2(1):2. [doi: 10.3390/bdcc2010002]

84. Farhadloo M, Winneg K, Chan MS, Hall Jamieson K, Albarracin D. Associations of topics of discussion on Twitter with survey measures of attitudes, knowledge, and behaviors related to Zika: probabilistic study in the United States. JMIR Public Health Surveill 2018 Feb 09;4(1):e16. [doi: 10.2196/publichealth.8186] [Medline: 29426815]

85. Majumder MS, Santillana M, Mekaru SR, McGinnis DP, Khan K, Brownstein JS. Utilizing nontraditional data sources for near real-time estimation of transmission dynamics during the 2015-2016 Colombian Zika virus disease outbreak. JMIR Public Health Surveill 2016 Jun 01;2(1):e30. [doi: 10.2196/publichealth.5814] [Medline: 27251981]

86. Miller M, Banerjee T, Muppalla R, Romine W, Sheth A. What are people tweeting about Zika? an exploratory study concerning its symptoms, treatment, transmission, and prevention. JMIR Public Health Surveill 2017 Jun 19;3(2):e38. [doi: 10.2196/publichealth.7157] [Medline: 28630032]

87. Stefanidis A, Vraga E, Lamprianidis G, Radzikowski J, Delamater PL, Jacobsen KH, et al. Zika in Twitter: temporal variations of locations, actors, and concepts. JMIR Public Health Surveill 2017 Apr 20;3(2):e22. [doi: 10.2196/publichealth.6925] [Medline: 28428164]

88. Sanz-Lorente M, Wanden-Berghe C, Castejón-Bolea R, Sanz-Valero J. Web 2.0 tools in the prevention of curable sexually transmitted diseases: scoping review. J Med Internet Res 2018 Mar 22;20(3):e113. [doi: 10.2196/jmir.8871] [Medline: 29567633]

89. Wongkoblap A, Vadillo MA, Curcin V. Researching mental health disorders in the era of social media: systematic review. J Med Internet Res 2017 Jun 29;19(6):e228. [doi: 10.2196/jmir.7215] [Medline: 28663166]

90. Athilingam P, Jenkins B. Mobile phone apps to support heart failure self-care management: integrative review. JMIR Cardio 2018 May 02;2(1):e10057. [doi: 10.2196/10057] [Medline: 31758762]

91. Gohil S, Vuik S, Darzi A. Sentiment analysis of health care tweets: review of the methods used. JMIR Public Health Surveill 2018 Apr 23;4(2):e43. [doi: 10.2196/publichealth.5789] [Medline: 29685871]

92. Mavragani A, Ochoa G, Tsagarakis KP. Assessing the methods, tools, and statistical approaches in Google Trends research: systematic review. J Med Internet Res 2018 Nov 06;20(11):e270. [doi: 10.2196/jmir.9366] [Medline: 30401664]

93. Hanson CL, Cannon B, Burton S, Giraud-Carrier C. An exploration of social circles and prescription drug abuse through Twitter. J Med Internet Res 2013 Sep 06;15(9):e189. [doi: 10.2196/jmir.2741] [Medline: 24014109]

94. Katsuki T, Mackey TK, Cuomo R. Establishing a link between prescription drug abuse and illicit online pharmacies: analysis of Twitter data. J Med Internet Res 2015 Dec 16;17(12):e280. [doi: 10.2196/jmir.5144] [Medline: 26677966]

95. Peiper NC, Baumgartner PM, Chew RF, Hsieh YP, Bieler GS, Bobashev GV, et al. Patterns of Twitter behavior among networks of cannabis dispensaries in California. J Med Internet Res 2017 Jul 04;19(7):e236. [doi: 10.2196/jmir.7137] [Medline: 28676471]

96. Yom-Tov E, Lev-Ran S. Adverse reactions associated with cannabis consumption as evident from search engine queries. JMIR Public Health Surveill 2017 Oct 26;3(4):e77. [doi: 10.2196/publichealth.8391] [Medline: 29074469]

97. Cavazos-Rehg P, Krauss M, Grucza R, Bierut L. Characterizing the followers and tweets of a marijuana-focused Twitter handle. J Med Internet Res 2014 Jun 27;16(6):e157. [doi: 10.2196/jmir.3247] [Medline: 24974893]

98. Ricard BJ, Marsch LA, Crosier B, Hassanpour S. Exploring the utility of community-generated social media content for detecting depression: an analytical study on Instagram. J Med Internet Res 2018 Dec 06;20(12):e11817. [doi: 10.2196/11817] [Medline: 30522991]

99. Seabrook EM, Kern ML, Fulcher BD, Rickard NS. Predicting depression from language-based emotion dynamics: longitudinal analysis of Facebook and Twitter status updates. J Med Internet Res 2018 May 08;20(5):e168. [doi: 10.2196/jmir.9267] [Medline: 29739736]

100. Tana JC, Kettunen J, Eirola E, Paakkonen H. Diurnal variations of depression-related health information seeking: case study in Finland using Google Trends data. JMIR Ment Health 2018 May 23;5(2):e43. [doi: 10.2196/mental.9152] [Medline: 29792291]

101. DeJohn AD, Schulz EE, Pearson AL, Lachmar EM, Wittenborn AK. Identifying and understanding communities using Twitter to connect about depression: cross-sectional study. JMIR Ment Health 2018 Nov 05;5(4):e61. [doi: 10.2196/mental.9533] [Medline: $\underline{30401662]}$

102. Jung H, Park H, Song T. Ontology-based approach to social data sentiment analysis: detection of adolescent depression signals. J Med Internet Res 2017 Jul 24;19(7):e259. [doi: 10.2196/jmir.7452] [Medline: 28739560]

103. Lachmar EM, Wittenborn AK, Bogen KW, McCauley HL. \#MyDepressionLooksLike: examining public discourse about depression on Twitter. JMIR Ment Health 2017 Oct 18;4(4):e43. [doi: 10.2196/mental.8141] [Medline: 29046270] 
104. Schlichthorst M, King K, Turnure J, Sukunesan S, Phelps A, Pirkis J. Influencing the conversation about masculinity and suicide: evaluation of the Man Up multimedia campaign using Twitter data. JMIR Ment Health 2018 Feb 15;5(1):e14. [doi: 10.2196/mental.9120] [Medline: 29449203]

105. Wong PW, Fu K, Yau RS, Ma HH, Law Y, Chang S, et al. Accessing suicide-related information on the internet: a retrospective observational study of search behavior. J Med Internet Res 2013 Jan 11;15(1):e3. [doi: 10.2196/jmir.2181] [Medline: 23305632]

106. Braithwaite SR, Giraud-Carrier C, West J, Barnes MD, Hanson CL. Validating machine learning algorithms for Twitter data against established measures of suicidality. JMIR Ment Health 2016 May 16;3(2):e21. [doi: 10.2196/mental.4822] [Medline: 27185366]

107. Cheng Q, Li TM, Kwok C, Zhu T, Yip PS. Assessing suicide risk and emotional distress in Chinese social media: a text mining and machine learning study. J Med Internet Res 2017 Jul 10;19(7):e243. [doi: 10.2196/jmir.7276] [Medline: 28694239]

108. Lee D, Lee H, Choi M. Examining the relationship between past orientation and US suicide rates: an analysis using big data-driven Google search queries. J Med Internet Res 2016 Feb 11;18(2):e35. [doi: 10.2196/jmir.4981] [Medline: 26868917]

109. Rose SW, Jo CL, Binns S, Buenger M, Emery S, Ribisl KM. Perceptions of menthol cigarettes among Twitter users: content and sentiment analysis. J Med Internet Res 2017 Feb 27;19(2):e56. [doi: 10.2196/jmir.5694] [Medline: 28242592]

110. Ayers JW, Westmaas JL, Leas EC, Benton A, Chen Y, Dredze M, et al. Leveraging big data to improve health awareness campaigns: a novel evaluation of the great American smokeout. JMIR Public Health Surveill 2016;2(1):e16. [doi: 10.2196/publichealth.5304] [Medline: 27227151]

111. de Viron S, Suggs LS, Brand A, Van Oyen H. Communicating genetics and smoking through social media: are we there yet? J Med Internet Res 2013 Sep 09;15(9):e198. [doi: 10.2196/jmir.2653] [Medline: 24018012]

112. Duke JC, Hansen H, Kim AE, Curry L, Allen J. The use of social media by state tobacco control programs to promote smoking cessation: a cross-sectional study. J Med Internet Res 2014 Jul 10;16(7):e169. [doi: 10.2196/jmir.3430] [Medline: $\underline{25014311]}$

113. Myslín M, Zhu S, Chapman W, Conway M. Using twitter to examine smoking behavior and perceptions of emerging tobacco products. J Med Internet Res 2013 Aug 29;15(8):e174. [doi: 10.2196/jmir.2534] [Medline: 23989137]

114. Rocheleau M, Sadasivam RS, Baquis K, Stahl H, Kinney RL, Pagoto SL, et al. An observational study of social and emotional support in smoking cessation Twitter accounts: content analysis of tweets. J Med Internet Res 2015 Jan 14;17(1):e18. [doi: 10.2196/jmir.3768] [Medline: 25589009]

115. Lienemann BA, Unger JB, Cruz TB, Chu K. Methods for coding tobacco-related Twitter data: a systematic review. J Med Internet Res 2017 Mar 31;19(3):e91. [doi: 10.2196/jmir.7022] [Medline: 28363883]

116. Staal YC, van de Nobelen S, Havermans A, Talhout R. New tobacco and tobacco-related products: early detection of product development, marketing strategies, and consumer interest. JMIR Public Health Surveill 2018 May 28;4(2):e55. [doi: 10.2196/publichealth.7359] [Medline: 29807884]

117. Zhan Y, Liu R, Li Q, Leischow SJ, Zeng DD. Identifying topics for e-cigarette user-generated contents: a case study from multiple social media platforms. J Med Internet Res 2017 Jan 20;19(1):e24. [doi: 10.2196/jmir.5780] [Medline: 28108428]

118. Allem J, Ferrara E, Uppu SP, Cruz TB, Unger JB. E-cigarette surveillance with social media data: social bots, emerging topics, and trends. JMIR Public Health Surveill 2017 Dec 20;3(4):e98. [doi: 10.2196/publichealth.8641] [Medline: 29263018]

119. Chen AT, Zhu S, Conway M. What online communities can tell us about electronic cigarettes and hookah use: a study using text mining and visualization techniques. J Med Internet Res 2015 Sep 29;17(9):e220. [doi: 10.2196/jmir.4517] [Medline: 26420469]

120. Chu K, Sidhu AK, Valente TW. Electronic cigarette marketing online: a multi-site, multi-product comparison. JMIR Public Health Surveill 2015;1(2):e11. [doi: 10.2196/publichealth.4777] [Medline: 27227129]

121. Cole-Lewis H, Pugatch J, Sanders A, Varghese A, Posada S, Yun C, et al. Social listening: a content analysis of e-cigarette discussions on Twitter. J Med Internet Res 2015 Oct 27;17(10):e243. [doi: 10.2196/jmir.4969] [Medline: 26508089]

122. Cole-Lewis H, Varghese A, Sanders A, Schwarz M, Pugatch J, Augustson E. Assessing electronic cigarette-related tweets for sentiment and content using supervised machine learning. J Med Internet Res 2015 Aug 25;17(8):e208. [doi: 10.2196/jmir.4392] [Medline: 26307512]

123. Harris JK, Moreland-Russell S, Choucair B, Mansour R, Staub M, Simmons K. Tweeting for and against public health policy: response to the Chicago Department of Public Health's electronic cigarette Twitter campaign. J Med Internet Res 2014 Oct 16;16(10):e238. [doi: 10.2196/jmir.3622] [Medline: 25320863]

124. Kim AE, Hopper T, Simpson S, Nonnemaker J, Lieberman AJ, Hansen H, et al. Using Twitter data to gain insights into e-cigarette marketing and locations of use: an infoveillance study. J Med Internet Res 2015 Nov 06;17(11):e251. [doi: 10.2196/jmir.4466] [Medline: 26545927]

125. Kim A, Miano T, Chew R, Eggers M, Nonnemaker J. Classification of Twitter users who tweet about e-cigarettes. JMIR Public Health Surveill 2017 Sep 26;3(3):e63. [doi: 10.2196/publichealth.8060] [Medline: 28951381]

126. Lazard AJ, Saffer AJ, Wilcox GB, Chung AD, Mackert MS, Bernhardt JM. E-cigarette social media messages: a text mining analysis of marketing and consumer conversations on Twitter. JMIR Public Health Surveill 2016 Dec 12;2(2):e171. [doi: 10.2196/publichealth.6551] [Medline: 27956376] 
127. Allem J, Ramanujam J, Lerman K, Chu K, Boley Cruz T, Unger JB. Identifying sentiment of hookah-related posts on Twitter. JMIR Public Health Surveill 2017 Oct 18;3(4):e74. [doi: 10.2196/publichealth.8133] [Medline: 29046267]

128. Cawkwell PB, Lee L, Weitzman M, Sherman SE. Tracking hookah bars in New York: utilizing Yelp as a powerful public health tool. JMIR Public Health Surveill 2015;1(2):e19. [doi: 10.2196/publichealth.4809] [Medline: 27227137]

129. Zhang Y, Allem J, Unger JB, Boley Cruz T. Automated identification of hookahs (waterpipes) on Instagram: an application in feature extraction using convolutional neural network and support vector machine classification. J Med Internet Res 2018 Nov 21;20(11):e10513. [doi: 10.2196/10513] [Medline: 30452385]

130. Allem J, Dharmapuri L, Leventhal AM, Unger JB, Boley Cruz T. Hookah-related posts to Twitter from 2017 to 2018 : thematic analysis. J Med Internet Res 2018 Nov 19;20(11):e11669. [doi: 10.2196/11669] [Medline: 30455162]

131. Liu Y, Mei Q, Hanauer DA, Zheng K, Lee JM. Use of social media in the diabetes community: an exploratory analysis of diabetes-related tweets. JMIR Diabetes 2016 Nov 07;1(2):e4. [doi: 10.2196/diabetes.6256] [Medline: $\underline{30291053]}$

132. Martinez M, Park SB, Maison I, Mody V, Soh LS, Parihar HS. iOS appstore-based phone apps for diabetes management: potential for use in medication adherence. JMIR Diabetes 2017 Jul 11;2(2):e12. [doi: 10.2196/diabetes.6468] [Medline: $\underline{30291096]}$

133. Oser TK, Oser SM, McGinley EL, Stuckey HL. A novel approach to identifying barriers and facilitators in raising a child with type 1 diabetes: qualitative analysis of caregiver blogs. JMIR Diabetes 2017 Oct 26;2(2):e27. [doi: 10.2196/diabetes.8966] [Medline: $\underline{30291073]}$

134. Sinnenberg L, Mancheno C, Barg FK, Asch DA, Rivard CL, Horst-Martz E, et al. Content analysis of metaphors about hypertension and diabetes on Twitter: exploratory mixed-methods study. JMIR Diabetes 2018 Dec 21;3(4):e11177. [doi: 10.2196/11177] [Medline: 30578222$]$

135. Xu X, Litchman ML, Gee PM, Whatcott W, Chacon L, Holmes J, et al. Predicting prediabetes through Facebook postings: protocol for a mixed-methods study. JMIR Res Protoc 2018 Dec 14;7(12):e10720. [doi: 10.2196/10720] [Medline: 30552084]

136. Arnhold M, Quade M, Kirch W. Mobile applications for diabetics: a systematic review and expert-based usability evaluation considering the special requirements of diabetes patients age 50 years or older. J Med Internet Res 2014 Apr 09;16(4):e104. [doi: 10.2196/jmir.2968] [Medline: 24718852]

137. Koschack J, Weibezahl L, Friede T, Himmel W, Makedonski P, Grabowski J. Scientific versus experiential evidence: discourse analysis of the chronic cerebrospinal venous insufficiency debate in a multiple sclerosis forum. J Med Internet Res 2015 Jul 01;17(7):e159. [doi: 10.2196/jmir.4103] [Medline: 26133525]

138. Risson V, Saini D, Bonzani I, Huisman A, Olson M. Patterns of treatment switching in multiple sclerosis therapies in US patients active on social media: application of social media content analysis to health outcomes research. J Med Internet Res 2016 Mar 17;18(3):e62. [doi: 10.2196/jmir.5409] [Medline: 26987964]

139. Tapi Nzali MD, Bringay S, Lavergne C, Mollevi C, Opitz T. What patients can tell us: topic analysis for social media on breast cancer. JMIR Med Inform 2017 Jul 31;5(3):e23. [doi: 10.2196/medinform.7779] [Medline: 28760725]

140. Vasconcellos-Silva PR, Carvalho DBF, Trajano V, de La Rocque LR, Sawada ACMB, Juvanhol LL. Using Google Trends data to study public interest in breast cancer screening in Brazil: why not a pink February? JMIR Public Health Surveill 2017 Apr 06;3(2):e17. [doi: 10.2196/publichealth.7015] [Medline: 28385679]

141. Huesch M, Chetlen A, Segel J, Schetter S. Frequencies of private mentions and sharing of mammography and breast cancer terms on Facebook: a pilot study. J Med Internet Res 2017 Jun 09;19(6):e201. [doi: 10.2196/jmir.7508] [Medline: 28600279]

142. Jones J, Pradhan M, Hosseini M, Kulanthaivel A, Hosseini M. Novel approach to cluster patient-generated data into actionable topics: case study of a web-based breast cancer forum. JMIR Med Inform 2018 Nov 29;6(4):e45. [doi: 10.2196/medinform.9162] [Medline: $\underline{30497991]}$

143. Vickey T, Breslin JG. Online influence and sentiment of fitness tweets: analysis of two million fitness tweets. JMIR Public Health Surveill 2017 Oct 31;3(4):e82. [doi: 10.2196/publichealth.8507] [Medline: 29089294]

144. Edney S, Bogomolova S, Ryan J, Olds T, Sanders I, Maher C. Creating engaging health promotion campaigns on social media: observations and lessons from Fitbit and Garmin. J Med Internet Res 2018 Dec 10;20(12):e10911. [doi: 10.2196/10911] [Medline: 30530449]

145. Madden KM. The seasonal periodicity of healthy contemplations about exercise and weight loss: ecological correlational study. JMIR Public Health Surveill 2017 Dec 13;3(4):e92. [doi: 10.2196/publichealth.7794] [Medline: 29237582]

146. Wang H, Chen D. Economic recession and obesity-related internet search behavior in Taiwan: analysis of Google Trends data. JMIR Public Health Surveill 2018 Apr 06;4(2):e37. [doi: 10.2196/publichealth.7314] [Medline: 29625958]

147. Sugawara Y, Narimatsu H, Tsuya A, Tanaka A, Fukao A. Medical institutions and Twitter: a novel tool for public communication in Japan. JMIR Public Health Surveill 2016;2(1):e19. [doi: 10.2196/publichealth.4831] [Medline: 27227154]

148. Xu S, Markson C, Costello KL, Xing CY, Demissie K, Llanos AA. Leveraging social media to promote public health knowledge: example of cancer awareness via Twitter. JMIR Public Health Surveill 2016;2(1):e17. [doi: 10.2196/publichealth.5205] [Medline: 27227152]

149. Surian D, Nguyen DQ, Kennedy G, Johnson M, Coiera E, Dunn AG. Characterizing Twitter discussions about HPV vaccines using topic modeling and community detection. J Med Internet Res 2016 Aug 29;18(8):e232. [doi: 10.2196/jmir.6045] [Medline: 27573910] 
150. Dunn AG, Leask J, Zhou X, Mandl KD, Coiera E. Associations between exposure to and expression of negative opinions about human papillomavirus vaccines on social media: an observational study. J Med Internet Res 2015 Jun 10;17(6):e144. [doi: 10.2196/jmir.4343] [Medline: 26063290]

151. Lama Y, Chen T, Dredze M, Jamison A, Quinn SC, Broniatowski DA. Discordance between human papillomavirus Twitter images and disparities in human papillomavirus risk and disease in the United States: mixed-methods analysis. J Med Internet Res 2018 Sep 14;20(9):e10244. [doi: 10.2196/10244] [Medline: 30217792]

152. Mahoney LM, Tang T, Ji K, Ulrich-Schad J. The digital distribution of public health news surrounding the human papillomavirus vaccination: a longitudinal infodemiology study. JMIR Public Health Surveill 2015;1(1):e2. [doi: 10.2196/publichealth.3310] [Medline: 27227125]

153. Massey PM, Leader A, Yom-Tov E, Budenz A, Fisher K, Klassen AC. Applying multiple data collection tools to quantify human papillomavirus vaccine communication on Twitter. J Med Internet Res 2016 Dec 05;18(12):e318. [doi: 10.2196/jmir.6670] [Medline: 27919863]

154. Nakada H, Yuji K, Tsubokura M, Ohsawa Y, Kami M. Development of a national agreement on human papillomavirus vaccination in Japan: an infodemiology study. J Med Internet Res 2014 May 15;16(5):e129. [doi: 10.2196/jmir.2846] [Medline: 24834471]

155. PRISMA. PRISMA statement URL: http://www.prisma-statement.org/PRISMAStatement/

156. Tricco AC, Lillie E, Zarin W, O'Brien KK, Colquhoun H, Levac D, et al. PRISMA extension for scoping reviews (PRISMA-ScR): checklist and explanation. Ann Intern Med 2018 Oct 02;169(7):467-473. [doi: 10.7326/M18-0850] [Medline: 30178033]

157. Journal of Medical Internet Research. E-collection 'Infodemiology and Infoveillance' URL: https://www.jmir.org/themes/ $\underline{69}$

158. JMIR Public Health and Surveillance. E-collection 'Infoveillance, Infodemiology and Digital Disease Surveillance' URL: https://publichealth.jmir.org/collection/view/304

\author{
Abbreviations \\ e-cigarettes: electronic cigarettes \\ e-collections: electronic collections \\ HPV: human papillomavirus \\ PRISMA: Preferred Reporting Items for Systematic Reviews and Meta-Analyses \\ STD: sexually transmitted disease
}

Edited by G Eysenbach; submitted 10.09.19; peer-reviewed by T Bernardo, C Liang, L Sun, W Marlicz; comments to author 02.02.20;
revised version received 05.02.20; accepted 08.02.20; published 28.04.20
Please cite as:
Mavragani A
Infodemiology and Infoveillance: Scoping Review
J Med Internet Res 2020;22(4):e16206
URL: $\underline{\text { http://www.jmir.org/2020/4/e16206/ }}$
doi: $10.2196 / 16206$
PMID: $\underline{32310818}$

(C)Amaryllis Mavragani. Originally published in the Journal of Medical Internet Research (http://www.jmir.org), 28.04.2020. This is an open-access article distributed under the terms of the Creative Commons Attribution License (https://creativecommons.org/licenses/by/4.0/), which permits unrestricted use, distribution, and reproduction in any medium, provided the original work, first published in the Journal of Medical Internet Research, is properly cited. The complete bibliographic information, a link to the original publication on http://www.jmir.org/, as well as this copyright and license information must be included. 